\title{
SULT1E1 wt Allele
}

National Cancer Institute

\section{Source}

National Cancer Institute. SULT1E1 wt Allele. NCI Thesaurus. Code C105992.

Human SULT 1E1 wild-type allele is located in the vicinity of 4q13.1 and is approximately $49 \mathrm{~kb}$ in length. This allele, which encodes estrogen sulfotransferase protein, is involved in the metabolism of estrogen. 